\title{
CrimRxiv
}

\section{'Tightness', autonomy and release: The anticipated pains of release and life licencing}

\author{
Ailie Rennie, Ben Crewe
}

Published on: Mar 05, 2022

DOI: $10.21428 / \mathrm{cb} 6 \mathrm{ab} 371.788 \mathrm{c0e} 6 \mathrm{f}$

License: Creative Commons Attribution 4.0 International License (CC-BY 4.0). 
